\title{
Hukum Produktifitas Zakat Fitrah
}

\author{
Oleh : Imamul Muttaqin \\ Guru MAN 2 Medan
}

\begin{abstract}
So far, zakat productivity has only been focused on zakat mal, the productivity of zakat al-Fitr has not been touched at all by BAZ and LAZ, even though the potential of community economic empowerment through the productivity of zakat fitrah is very large if managed properly and responsibly and if fulfilling certain conditions to produce zakat fitrah, this article will discuss in detail the law of producing zakat fitrah, which is how it stands in Islamic law, whether the productivity of zakat fitrah is justified in Islamic law
\end{abstract}

Kata-kata Kunci : Pemberdayaan, Produktifitas, Zakat Fitrah

\section{A. Pendahuluan.}

Saat ini, produktifitas zakat hanya terbatas pada produktifitas zakat mal saja, produktifitas zakat fitrah bahkan belum tersentuh oleh BAZ dan LAZ. Pemberdayaan ekonomi umat melalui produktifitas zakat mal, merupakan hal yang sudah dikategorikan biasa pada masa sekarang, karena seluruh BAZ dan LAZ di Indonesia telah mengelola zakat mal secara produktif tidak konsumtif, sehingga mustahak zakat tidak langsung menerima harta zakat, karena dengan demikian zakat itu akan langsung habis begitu saja tanpa ada sisa, hal itu sangat merugikan pihak mustahak zakat. Menanggapi sifat konsumtif zakat mal, maka perlu dilakukan pengelolaan zakat yang profesional agar hasilnya dapat dinikmati oleh mustahak, bahkan dapat merubah posisi mustahak menjadi seorang muzakki.

Zakat fitrah merupakan zakat yang wajib ditunaikan oleh setiap umat Islam yang mampu seusai melaksanakan puasa Ramadan. Selama ini pemahaman masyarakat bahwa zakat fitrah sifatnya adalah konsumtif, artinya yaitu zakat fitrah harus diserahkan dan dibagikan sebelum pelaksanaan salat idul fitri dan harus habis pada hari itu juga. Pemahaman seperti ini merupakan pemahaman yang bernas, bersumber dari hadis Ibnu $\mathrm{Umar}^{1}$ :

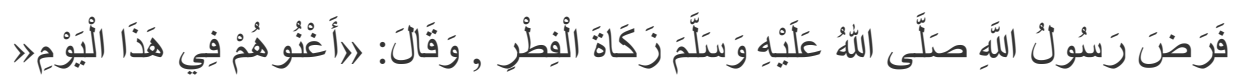

${ }^{1}$ Abul Hasan Ali ibn Umar al-Daru Qutni, Sunan Dar al-Qutni (Beirut : Muassasah Risalah, 2004), jil 3, h. 89. Nomoar hadis ke-2133. 
"Rasulullah saw mewajibkan zakat fitri dan bersabda, 'Cukupkan kebutuhan mereka (fakir miskin dari meminta-minta) pada hari itu'." (HR. Daruqutni).

Namun jika ditinjau dari dalil lain yang bersifat umum mengenai pengembangan Zakat, pengelolaan zakat secara produktif dapat dijumpai dari hadis Rasulullah $\operatorname{saw}^{2}$ :

عن سالم بن عبد الله بن عمر عن أبيه أن رسول الله مني فيقول خذه فتموله أو تصدق به وما جاءك من هذا المال و أنت غير مشرف ونلا سائل سئل فخذه وما لا فلا تتبعه نفسك.

"Dari Salim bin Abdullah bin Umar dari ayahnya bahwa Rasul saw pernah memberikan sedekah kepada Umar, namun Umar menolak seraya berkata : berikanlah sedekah ini kepada orang yang lebih membutuhkan dariku. Kemudian Rasulullah menjawab : ambillah dan kembangkanlah (produktifkanlah) atau sedekahkanlah kepada orang lain. Sesungguhnya harta yang datang kepadamu sedangkan engkau tidak berambisi dan tidak memintanya, maka ambillah. Dan apabila harta itu tidak datang kepadamu maka janganlah engkau mengikuti hawa nafsumu.

Dalam hadis di atas rasul mengatakan maka kembangkanlah maksudnya adalah sedekah yang kita terima jika melebihi dari kebutuhan pokok kita maka hendaknya diproduktifkan sehingga menjadi berkembang dan lebih bermanfaat.

Selain itu menurut Imam Nawawi dalam al-Majmu’ Syarah al-Muhazzab, ketika seorang memiliki kemampuan yang dapat mengembangkan profesinya dia boleh mendapatkan alat dari hasil zakat, di mana dengan alat itu dia dapat bekerja dan menghasilkan uang bahkan merubah kondisinya dari mustahak menjadi muzakki, :

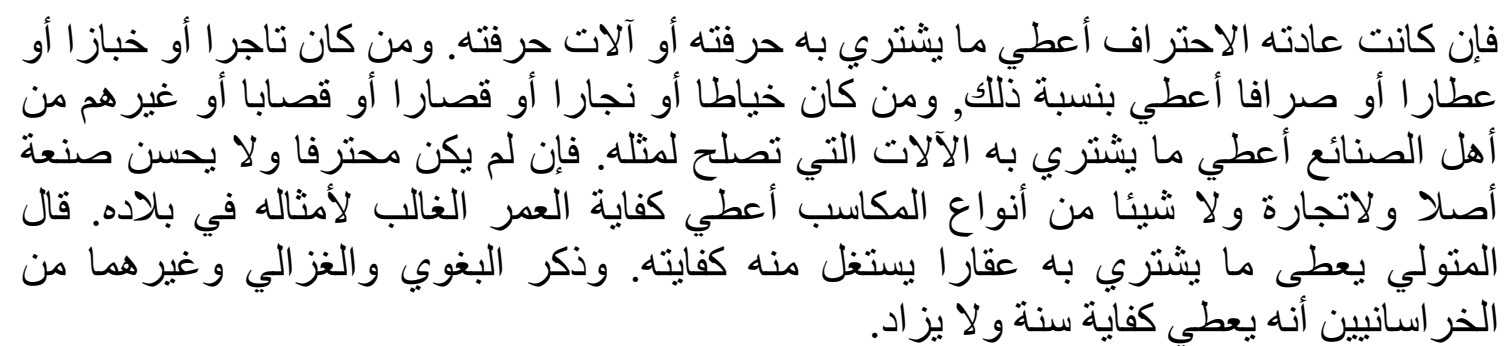

"Jika seorang fakir kebiasaannya adalah bekerja, maka baginya dibelikan sesuatu untuk memenuhi pekerjaannya atau membeli alat yang sesuai dengan pekerjaannya. Seorang pedagang, tukang roti, tukang bangunan diberikan zakat sesuai dengan profesi mereka, tukang jahit, tukang kayu, penatu dan sebagainya yang merupakan pekerja diberikan kepada mereka zakat yang dapat membeli alat-alat kerja yang sesuai dengan pekerjaan mereka, Apabila seorang fakir itu tidak mampu bekerja, tidak bisa melakukan suatu perbuatan, berupa dagang dan jenis pekerjaan lainnya, maka atasnya diberikan zakat untuk seumur hidupnya menurut ukuran umum, Imam Mutawalli berpendapat dibelikan kepadanya bangunan rumah yang dapat mencukupi

\footnotetext{
${ }^{2}$ Muhammad bin Ismâîl al-Kah lânî Subûl al-Salâm (Beirût : Dâr al-Fikr), Jil 2, h. 149. Abû Abdillâh Muhammad bin Ismâil al-Bukhârî, Jami al-Shahîh al-Bukhârî (Beirût : al-Maktabah al-Ashriyyah), Nomor Hadits 6630. Abû Abd al-Rahmân Ahmad bin Syu'aib al-Nasâ'̂̂, Sunan al Nasâ (Riyâdh : Maktabah al-Ma'ârif, 1998), Nomor Hadits 2559. Ah mad bin Hanbal, Musnad al-

Imâm Ah mad bin Hanbal (Beirût : Dâr al-Fikr), Nomor Hadits 96.
} 
kebutuhannya, Imam Baghawi, Imam Ghazali dan sebagainya dari penduduk Khurasan berpendapat diberikan kepadanya zakat untuk kecukupan hidup setahun ${ }^{3}$.

Peraturan perundang-undangan yang berlaku di Indonesia mendukung penuh terhadap pengelolaan zakat untuk kesejahteraan masyarakat Indonesia, hal ini terdapat dalam Undang-Undang Nomor 23 Tahun 2011 tentang pengelolaan zakat dalam pasal 3 disebutkan bahwa pengelolaan zakat bertujuan : meningkatkan efektivitas dan efisiensi pelayanan dalam pengelolaan zakat dan meningkatkan manfaat zakat untuk mewujudkan kesejahteraan masyarakat dan penanggulangan kemiskinan. ${ }^{4}$ Ini artinya bahwa pemerintah telah memfasilitasi terciptanya pengelolaan zakat yang dapat memberikan aspek ekonomi, syari'ah dan bertanggung jawab bagi pengelola dan wajib zakat serta pihak yang menerimanya. Dalam sejarah perzakatan di Indonesia, Pengelolaan zakat secara konvensional dilakukan dari tangan ke tangan. Maksudnya wajib zakat atau mengeluarkan zakatnya dengan memberikan secara langsung kepada pihak yang berhak menerimanya. Dengan demikian, maka penyerahan berlangsung secara sederhana, cepat dan langsung.

Menurut Undang-Undang Nomor 23 Tahun 2011 tentang pengelolaan zakat dalam pengertian memproduktifkan zakat fitrah untuk memberdayakan ekonomi umat dengan membangun daya (masyarakat) dengan mendorong, memotivasi, dan membangkitkan kesadaran akan potensi ekonomi yang dimilikinya serta berupaya untuk mengembangkannya, Zakat fitrah itu memiliki manfaat serta dapat memajukan ekonomi umat.

Produktifitas zakat fitrah, dengan tidak memberikan secara langsung kepada mustahak dan tidak menghabiskan zakat pada saat itu juga merupakan terobosan baru yang munkin banyak mendapatkan hambatan serta kesulitan, karena asumsi masyarakat selama ini adalah zakat fitrah itu bersifat konsumtif. Melalui makalah ini penulis berusaha untuk menemukan hukum terkait Pemberdayaan Ekonomi Umat Melalui Produktifitas Zakat Fitrah, yang didahului dengan tinjauan fikih terhadap produktifitas Zakat, kemudian Pemberdayaan Ekonomi Umat Melalui Produktifitas Zakat Fitrah dan contoh produktifitas Zakat Fitrah.

\section{B. Tinjauan Fikih Terhadap Pendayagunaan Zakat Secara Produktif}

\footnotetext{
${ }^{3}$ Muhyiddin Nawawi, al-Majmū' Syarah al-Muhażżab (Beirut : Dār al-Kutub Ilmiah, 2007), jil 7, h. 237.

${ }^{4}$ Undang Undang Zakat Tahun 2011 (Jakarta : Prenada Grup, 2013), h. 11.
} 
Secara etimologi dalam kamus Oxford Advanced Learner's Dictionary of Current English produktif berasal dari bahasa Inggris "productive" yang berarti able to produce (bring forward $)^{5}$ yaitu bisa berkembang, dapat melakukan kemajuan atau dapat menghasilkan perkembangan dan kemajuan. Secara umum produktif (productive) berarti banyak menghasilkan karya atau barang ${ }^{6}$. Produktif juga berarti banyak menghasilkan, memberikan banyak hasil ${ }^{7}$. Dalam bahasa Arab produktif disebut dengan الزَّكَاةُ ل dengan demikian dalam bahasa Arab zakat produktif disebut dengan الْإِنْنَاجِيَّةُ

Pengertian produktif dalam makalah ini lebih berkonotasi kepada kata sifat. Kata sifat akan jelas maknanya apabila digabung dengan kata yang disifatinya. Dalam hal ini kata yang disifati adalah kata zakat, 'zakat produktif'. Yaitu zakat yang produktif, zakat dimana dalam pendistribusiannya bersifat produktif lawan dari konsumtif.

Ditinjau dari terminologi menurut Asrifin An-Nakhrawie bahwa zakat produktif itu adalah zakat yang nantinya bisa menghasilkan sesuatu, zakat yang memberikan hasil yang menguntungkan dan akan terus berkembang ${ }^{9}$. Menurut Asnaini zakat produktif itu adalah pemberian zakat yang dapat membuat para penerimanya mengahasilkan sesuatu secara terus menerus, dengan harta zakat yang telah diterimanya. Dengan kata lain zakat produktif adalah zakat dimana harta atau dana zakat yang diberikan kepada para mustahik tidak dihabiskan akan tetapi dikembangkan dan digunakan untuk membantu usaha mereka, sehingga dengan usaha tersebut mereka dapat memenuhi kebutuhan hidup secara terus-menerus ${ }^{10}$.

Berdasarkan definisi yang telah disebutkan di atas bahwa inti dari zakat produktif itu lebih kepada bagaimana cara atau metode menyampaikan dana zakat kepada sasaran dalam pengertian yang lebih luas, sesuai dengan ruh dan tujuan syara'. Cara pemberian yang tepat guna, efektif manfaatnya dengan sistem yang serba guna dan produktif, sesuai dengan pesan syari'at dan peran serta fungsi sosial ekonomis dari zakat.

Jika dianalogikan, zakat produktif sama dengan memberi kail kepada golongan

\footnotetext{
5 AS Hornby, Oxford Advanced Learner's Dictionary of Current English (London : Oxford University Press, 1987), h. 666.

${ }^{6}$ Joyce M. Hawkins, Kamus Dwi Bahasa Inggris-Indonesia, Indonesia-Inggris (Jakarta : Erlangga, 1996), h. 267.

${ }^{7}$ Save M. Dagun, Kamus Besar Ilmu Pengetahuan (Jakarta : LPKN, 2000), h. 893.

8 Ahmad Warson Munawwir, Kamus al-Munawwir (Yogyakarta : Pustaka Progressif, 1997), h. 1382.

${ }^{9}$ Asifin An Nakhrawie, Sucikan Hati Dan Bertambah Kaya Bersama Zakat (Jakarta : Delta Prima Press, 2011), h. 163.

${ }^{10}$ Asnaini, Zakat Produktif Dalam Perspektif Hukum Islam (Buku, tidak diterbitkan), h. 70.
} 
lemah yaitu nelayan yang kurang mampu, kepadanya tidak langsung diberikan ikan, melainkan bagaimana agar zakat yang dikumpulkan itu tidak konsumtif didayagunakan terlebih dahulu secara produktif agar nelayan tersebut dapat terus menerus menikmati hasil dari pemberian zakat produktif. Maka dengan memberikan kail kepada nelayan, dia dapat mencari ikan dengan kail hasil dari zakat produktif.

Dalam prakteknya nanti zakat produktif bisa berupa modal kerja, berupa uang yang bisa digunakan sebagai modal atau dalam bentuk lain berupa hewan ternak yang bisa dijadikan sebagai lahan pekerjaan atau yang lain.

Lawan dari zakat produktif adalah zakat konsumtif. Zakat konsumtif itu adalah zakat yang diberikan kepada golongan lemah dalam bentuk barang untuk digunakan sebagai konsumsi. Biasanya zakat jenis ini diberikan dalam bentuk makanan atau uang tunai yang dipergunakan untuk keperluan hidup sehari-hari. Dalam zakat produktif ada upaya untuk mengembangkan harta zakat, tetapi dalam zakat konsumtif bersifat stagnan langsung habis seketika. Zakat produktif bisa berkembang namun pada zakat konsumtif tidak bisa berkembang.

Lebih jauh lagi, zakat produktif melatih seseorang agar giat berusaha mencari kekayaan agar bisa memenuhi kebutuhan hidup, sementara pada zakat konsumtif ada semacam pembelajaran mengharapkan pemberian dari orang lain sehingga malas untuk berusaha.

Mendayagunakan zakat secara produktif hingga benar-benar bisa menjadi upaya untuk menolong orang miskin dari keterpurukan bukanlah sebuah pemikiran yang bisa langsung diterima begitu saja di kalangan umat Islam. Dalam prakteknya, zakat produktif sepertinya masih jarang dilakukan oleh sebagian besar aghniy $\bar{a}$ atau bisa saja pemikiran seperti itu belum terlintas dalam pandangan mereka. Kebanyakan para aghniyā memberikan zakatnya secara tunai, diberikan secara langsung dalam bentuk uang.

Secara tekstual memang para ulama terdahulu di atas tidak menyebutkan secara detail harta zakat yang diperoleh apakah dibagikan secara konsumtif atau produktif. Hanya ulama fikih kontemporer saat sekarang ini yang lebih memfokuskan pembahasannya pada kebolehan dan larangan untuk memproduktifkan zakat. Diantara ulama fikih kontemporer yang agak ketat dalam melarang zakat produktif adalah, Abdullah Ulwan, Muhammad A’ta al-Sayyid dan Muhammad Taqiyyuddin Usmani ${ }^{11}$.

\footnotetext{
${ }^{11}$ Majalah Majma' al-Fiqhu al-Islami, cet III, jil 1, h. 335.
} 
Walaupun ulama terdahulu tidak menyebutkan pembahasan khusus mengenai zakat produktif dalam karya mereka namun dalam praktek pendistiribusian zakat ada indikasi yang mengarah kepada kebolehan untuk mendayagunakan zakat secara produktif, di mana ulama terdahulu ada yang membolehkan pemberian zakat kepada orang-orang miskin berupa alat pekerjaan yang sesuai dengan profesi orang tersebut, yang dapat dijadikan modal bagi mereka untuk pekerjaannya dan menekuni usahanya, agar hasilnya dapat mencukupi kebutuhan mereka dalam jangka waktu yang lama bukan hanya sesaat. Diantara ulama yang berpendapat demikian adalah :

1. Imam Muyiddin Nawawi

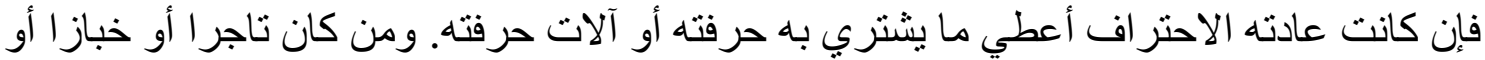

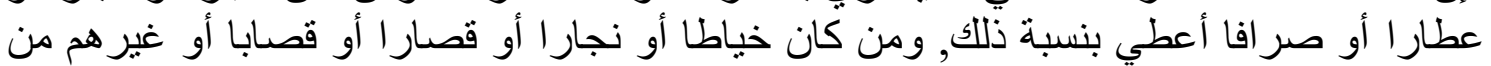

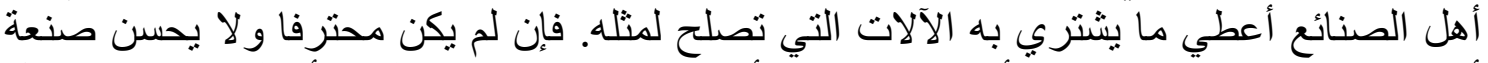

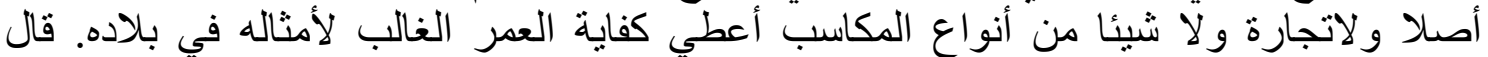

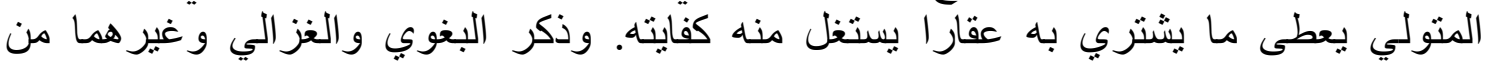

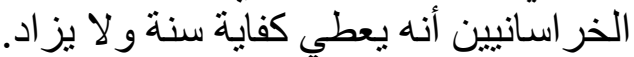

"Jika seorang fakir kebiasaannya adalah bekerja, maka baginya dibelikan sesuatu untuk memenuhi pekerjaannya atau membeli alat yang sesuai dengan pekerjaannya. Seorang pedagang, tukang roti, tukang bangunan diberikan zakat sesuai dengan profesi mereka, tukang jahit, tukang kayu, penatu dan sebagainya yang merupakan pekerja diberikan kepada mereka zakat yang dapat membeli alat-alat kerja yang sesuai dengan pekerjaan mereka, Apabila seorang fakir itu tidak mampu bekerja, tidak bisa melakukan suatu perbuatan, berupa dagang dan jenis pekerjaan lainnya, maka atasnya diberikan zakat untuk seumur hidupnya menurut ukuran umum, Imam Mutawalli berpendapat dibelikan kepadanya bangunan rumah yang dapat mencukupi kebutuhannya, Imam Baghawi, Imam Ghazali dan sebagainya dari penduduk Khurasan berpendapat diberikan kepadanya zakat untuk kecukupan hidup setahun ${ }^{12}$.

Dalam konteks kekinian pendapat Imam Nawawi di atas menyebutkan bahwa pembagian zakat itu terbagi dua, yaitu pembagian secara produktif dan konsumtif, hanya saja Imam Nawawi membatasi pembagian zakat secara produktif yaitu hanya kepada orang-orang fakir, miskin yang memang mampu untuk bekerja namun mereka tidak memiliki modal sebagai penunjang profesinya tersebut. Dari sini semakin nampak urgensi zakat produktif tersebut, orang-orang yang biasanya bekerja namun tidak memiliki modal untuk membeli alat-alat yang menjadi kebutuhannya dalam bekerja, dapat diberikan zakat berupa modal untuk membeli peralatannya.

Sedangkan zakat konsumtif itu menurut Imam Nawawi diberikan kepada golongan fakir, miskin yang memang sudah tidak mempunyai kemampuan untuk

\footnotetext{
${ }^{12}$ Muhyiddin Nawawi, al-Majmū’ Syarah al-Muhażżab (Beirut : Dār al-Kutub Ilmiah, 2007), jil 7 , h. 237.
} 
bekerja disebabkan oleh faktor usia, jika dipaksakan bekerja maka akan memberikan efek yang berbahaya bagi dirinya seperti sakit atau bahkan kematian. Dalam hal ini para ulama memberikan tiga opsi kepada orang yang tidak mampu bekerja. diberikan zakat untuk seumur hidupnya menurut ukuran umum, atau dibelikan kepadanya bangunan rumah yang dapat mencukupi kebutuhannya, atau diberikan kepadanya zakat untuk kecukupan hidup setahun.

Berbeda dengan pernyataan Imam Nawawi di atas, Imam Abu Ishaq al-Syirazi memberikan batasan dalam pendayagunaan zakat produktif. Artinya walaupun Imam Abu Ishaq membolehkan mendayagunakan zakat secara produktif namun ada syaratsyarat tertentu yang harus dipenuhi sebelum zakat itu diproduktifkan. Pernyataan Imam Abu Ishaq al-Syirazi yaitu ${ }^{13}$ :

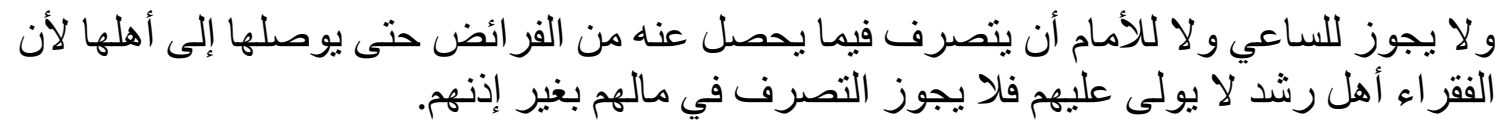

"Tidak diperbolehkan bagi amil begitu juga penguasa (pemerintah) untuk mendayagunakan zakat yang merupakan suatu perbuatan fardhu sebelum sampai kepada orang yang berhak menerimanya, karena orang-orang fakir tersebut merupakan ahlu rusyd (orang yang pandai mendayagunakan zakatnya sendiri), mereka juga tidak boleh menguasai zakat tersebut, dengan demikian tidak boleh mendayagunakan harta zakat sebelum mendapat izin dari mereka”.

Pernyataan Imam Abu Ishaq al-Syirazi di atas sebenarnya tidak jauh berbeda dari Imam Nawawi, pada dasarnya keduanya membolehkan pendayagunaan zakat secara produktif, hanya saja Imam Abu Ishaq agak ketat dalam hal ini, dia memberikan syarat agar harta zakat itu tidak diproduktifkan terlebih dahulu sebelum mendapatkan izin dari mustahik zakat. Karena tidak dapat dipungkiri bahwa terdapat di tengah-tengah masyarakat Islam yang pandai mendayagunakan harta zakat yang merupakan haknya hanya saja mungkin dia tidak memiliki modal untuk memenuhi kebutuhan pekerjaannya. Dengan harta zakat itu dia dapat mendayagunakannya sendiri. Selain itu juga menurut hemat penulis meminta izin untuk mendayagunakan zakat merupakan hal yang wajar, mengingat harta zakat itu merupakan hak mereka. Jadi mereka lebih berhak terhadap harta zakat itu.

Lain hal nya dengan ahlu balädah yaitu orang-orang yang memang tidak memiliki skill kemampuan untuk mendayagunakan harta zakat tersebut, sehingga ketika mereka menerima zakat, zakat tersebut akan habis begitu saja. Terhadap golongan seperti ini amil dan pemerintah mempunyai hak untuk mendayagunakan zakat mereka

\footnotetext{
${ }^{13}$ Abu Ishaq al-Syirazi, al-Muhażżab (Beirut : Dār Hikmah, t.t.), jil 1, h. 169.
} 
secara produktif demi kelangsungan hidup mereka, dengan catatan baik amil atau pemerintah hendaknya transparan dalam mendayagunakan zakat itu secara produktif sehingga ahlu balādah memiliki kepercayaan terhadap amil zakat dan pemerintah.

Adapun ulama kontemporer yang membolehkan pendayagunaan zakat produktif yaitu syaikh Yusuf al-Qardhawi. Dia menyatakan bahwa Negara Islam boleh membangun pabrik-pabrik, perusahaan-perusahaan, PT-PT dan sebagainya, kemudian dijadikan milik orang miskin seluruhnya atau sebagiannya. Dengan demikian usaha yang dimiliki dapat menghasilkan keuntungan dan dapat membiayai seluruh kebutuhan mereka. Akan tetapi jangan diberi hak menjual atau memindahkan hak miliknya kepada orang lain sehingga menyerupai harta wakaf bagi mereka ${ }^{14}$.

Selain Yusuf Qardhawi ada juga Syaikh Abdul Aziz al-Khiyat mantan dekan fakultas Syariah Yordan menyampaikan pandangannya bahwa pengembangan harta zakat dalam berbagai bentuk kebaikan apakah industri, perdagangan merupakan hal penting untuk mewujudkan mashlahat ${ }^{15}$.

Di Indonesia mayoritas para cendikiawan Islam, tokoh agama, para kiyai, pakar hukum Islam sangat menganjurkan pendayagunaan zakat produktif. Diantaranya K.H Sahal Mahfuzh di Pati melalui badan pengembangan masyarakat pesantren (BPPM) melaksanakan pengelolaan dana zakat kepada kaum fakir miskin melalui pendekatan kebutuhan dasar ini. Karena menurutnya ${ }^{16}$ : Pendekatan kebutuhan dasar bertujuan mengetahui kebutuhan dasar masyarakat (faqir miskin), sekaligus mengetahui apa latar belakang kemiskinan itu. Apabila si miskin itu mempunyai keterampilan menjahit maka diberi mesin jahit, kalau keterampilannya mengemudi becak, si faqir miskin itu diberi becak. Maka dalam hal ini, memberi motivasi kepada masyarakat miskin juga merupakan sesuatu yang sangat mendasar, agar mereka mau berusaha dan tidak sekedar menunggu uluran tangan orang kaya. Dan hal ini dilakukan secara riil oleh beliau dengan penuturannya: "Pernah suatu kali saya mencobanya terhadap seorang pengemudi becak di kabupaten Pati, saya lihat dia tekun mangkal di pasar untuk bekerja sebagai tukang becak. Pada saat pembagian zakat tiba, saya zakati dia. Hasil zakat bulan Syawal itu berupa zakat mal, zakat fitrah dan infaq. Semua saya kumpulkan dan sebagian saya belikan becak untuk nya. Sebelumnya dia hanya mengemudikan becak milik orang non pribumi, namun sekarang dia telah memiliki dua buah becak. Usaha itu berkembang dan

\footnotetext{
${ }^{14}$ Yusuf al-Qardhawi, Fiqhu al-Zakat (Beirut : Muassasah Risalah, 1991), h. 567.

${ }^{15}$ Al-Khiyat, Tawzīf amwāl al-Zakat F̄̄ Masyāri' Zakat F̄̄ Masyari' Dātī Ri 'in Bilā Tamlīk Fardiyy lilmustahiq, dalam majalah Majma' al-Fiqhu al-Islami, jili 1, h. 371.

${ }^{16}$ Sahal Mahfuzh, Nuansa Fiqh Sosial (Yogyakarta : LKIS, 2003), h. 119.
} 
sehari-hari ia tidak harus mengemudikan becak dengan mengejar setoran. Dengan mengemudikan becak sampai jam tiga sore, hasilnya sudah cukup untuk makan dan untuk menjaga kesehatan, setelah itu ia bisa kumpul-kumpul mengikuti pengajian. Dengan cara ini, meskipun dia tidak menjadi kaya, tetapi jelas ada perubahan."

K.H Sahal juga melembagakan dana zakat melalui koperasi. Dana zakat yang terkumpul tidak langsung diberikan dalam bentuk uang, mustahik diserahi zakat berupa uang tetapi kemudian ditarik kembali sebagai tabungan si miskin untuk keperluan pengumpulan modal. Menurutnya cara ini mereka fakir miskin dapat menciptakan pekerjaan dengan modal yang dikumpulkan dari harta zakat ${ }^{17}$.

Selain K.H Sahal, menurut A.M Saefuddin dalam pandangannya Pembagian zakat seharusnya didasarkan pada pendekatan struktural. Karena lebih mengutamakan pemberian pertolongan secara kontinu yang bertujuan agar si miskin atau fakir dapat mengatasi masalah kemiskinannya. Apabila penyebab kemiskinan itu adalah langkanya lapangan pekerjaan, maka pekerjaanlah yang harus disediakan bagi mereka. Bila penyebabnya adalah tiadanya modal usaha padahal memiliki kewiraswastaan maka sediakanlah dana untuk usaha warungan atau bakul, dan lain-lain. Kalau biang keladi kemiskinan atau kefakiran itu adalah kebodohan, maka wujudkanlah dana atau beasiswa pendidikan bagi mereka. Dengan pendekatan ini pemecahkan masalah kemiskinan itu tidak secara insidentil, tetapi mengubah dan memperbaiki penyebab yang paling dasar dari kemiskinan, kebodohan kemalasan, kelemahan, keterbelakangan, ketertinggalan dan lain-lain bentuk yang terkandung dalam kata majemuk duafa-fukoro-masakin ${ }^{18}$.

Pendapat Saefuddin ini disamping menyetujui cara pembagian zakat produktif, menurut penulis juga merinci bahwa zakat itu bisa berupa pemberian lapangan pekerjaan artinya 'amil dalam hal ini pemerintah dapat menciptakan lapangan pekerjaan dengan dana zakat seperti perusahaan, modal usaha atau bea siswa agar mereka memiliki suatu usaha yang tetap dan keterampilan serta ilmu untuk menopang hidup ke arah yang lebih baik dan layak.

Senada dengan pernyataan Saefuddin di atas Didin Hafidhuddin mantan Ketua BAZNAS sangat menganjurkan penunaian zakat tidak hanya sekedar konsumtif, hal ini dapat dilihat dari pernyataannya : Karena zakat merupakan hak bagi mustahiq, maka berfungsi untuk menolong, membantu dan membina mereka, terutama golongan fakir miskin ke arah kehidupan yang lebih baik dan lebih sejahtera, sehingga mereka dapat

\footnotetext{
${ }^{17}$ Ibid.

${ }^{18}$ A.M Saefuddin, Islam Untuk Disiplin Ilmu Ekonomi (Jakarta : Depag, 1986), h. 117.
} 
memenuhi kebutuhan hidupnya dengan layak. Bukan sekedar memenuhi kebutuhan yang bersifat konsumtif yang sifatnya sesaat, tetapi memberikan kecukupan dan kesejahteraan, dengan cara menghilangkan atau memperkecil penyebab kehidupan mereka menjadi miskin dan menderita ${ }^{19}$.

Masih menurut Didin bahwa bagi para pedagang yang sudah mampu memenuhi kebutuhan sehari-harinya pun boleh diberi pinjaman yang harus dikembalikan tanpa bunga dari dana zakat, apabila mereka membutuhkan dana tambahan untuk mengembangkan usahanya ${ }^{20}$.

Pernyataan-pernyataan para ulama, pakar hukum Islam, cendikiawan, para Kiyai dan sebagainya yang telah penulis sebutkan di atas yang cenderung menganjurkan pengelolaan zakat secara produktif didasari dari nas Alquran maupun hadis baik yang bersifat $\bar{a}$ 'm maupun Khass baik yang bersifat mujmal maupun mubayyan. Diantara nas yang dijadikan pedoman dalam menganjurkan pengelolaan zakat produktif yaitu terdapat dalam surah al-Taubah : 103 :

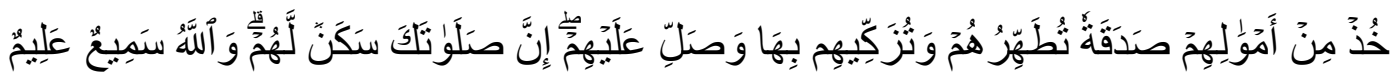
“Ambillah zakat dari sebagian harta mereka, dengan zakat itu kamu membersihkan dan mensucikan mereka dan mendoalah untuk mereka. Sesungguhnya doa kamu itu (menjadi) ketenteraman jiwa bagi mereka. dan Allah Maha mendengar lagi Maha mengetahui."

Lafaz tuzakkīhim dalam ayat di atas dapat berarti menyucikan dan dapat pula berarti mengembangkan sesuai dengan makna zakat secara bahasa yaitu التنمية 21 . Tidak hanya sekedar berkembang, zakat itu dapat terus diupayakan bertambah secara kontinuitas, karena makna tanmiyah menurut Fairuzabadi selalu digandengkan dengan kalimat الزيادة.

Selain nas yang berasal dari Alquran, pengelolaan zakat secara produktif dapat dijumpai dari hadis Rasulullah saw ${ }^{22}$ :

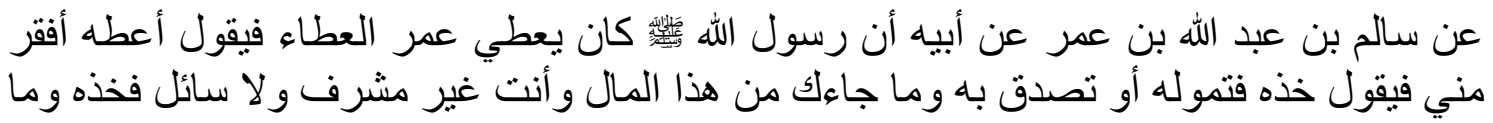

${ }^{19}$ Mukhtar Sadili, Problematika Zakat Kontemporer, ed. Amru (Jakarta : Forum Zakat, 2003), h. 181.

${ }^{20}$ Didin Hafidhuddin, Panduan Praktis Tentang ZIS (Jakarta : Gema Insani, 1998), h. 134.

${ }^{21}$ Lois Ma'luf, al-Munjid Fī al-Lughah (Beirut : Dār al-Masyriq, 1986), h. 303.

${ }^{22}$ Muhammad bin Ismâîl al-Kah lânî Subûl al-Salâm (Beirût : Dâr al-Fikr), Jil 2, h. 149. Abû Abdillâh Muhammad bin Ismâil al-Bukhârî, Jami al-Shahîh al-Bukhârî (Beirût : al-Maktabah alAshriyyah), Nomor Hadits 6630. Abû Abd al-Rahmân Ahmad bin Syu'aib al-Nasâ'î, Sunan al Nasâ (Riyâdh : Maktabah al-Ma'ârif, 1998), Nomor Hadits 2559. Ah mad bin Hanbal, Musnad al-

Imâm Ah mad bin Hanbal (Beirût : Dâr al-Fikr), Nomor Hadits 96. 
"Dari Salim bin Abdullah bin Umar dari ayahnya bahwa Rasul saw pernah memberikan sedekah kepada Umar, namun Umar menolak seraya berkata : berikanlah sedekah ini kepada orang yang lebih membutuhkan dariku. Kemudian Rasulullah menjawab : ambillah dan kembangkanlah (produktifkanlah) atau sedekahkanlah kepada orang lain. Sesungguhnya harta yang datang kepadamu sedangkan engkau tidak berambisi dan tidak memintanya, maka ambillah. Dan apabila harta itu tidak datang kepadamu maka janganlah engkau mengikuti hawa nafsumu.

Dalam hadis di atas rasul mengatakan maka kembangkanlah maksudnya adalah sedekah yang kita terima jika melebihi dari kebutuhan pokok kita maka hendaknya diproduktifkan sehingga menjadi berkembang dan lebih bermanfaat.

Jika Produktifitas zakat fitrah ini dapat dilakukan oleh para amil atau para pihak pengelola yang jujur dan dapat bertanggung jawab serta tidak berkhianat, harus memenuhi beberapa syarat ketentuan, yang menurut hemat penulis syarat itu adalah :

1. Pengelola zakat fitrah adalah orang yang jujur dan ahli dalam pengelolaan zakat fitrah.

2. Pengelolaan zakat fitrah ini harus diawasi oleh pihak badan kenaziran masjid, mengingat zakat fitrah ini panitianya adalah BKM yang bersifat temporal yaitu sesaat saja, setelah zakat fitrah itu dibagi, panitia zakat fitrah akan bubar secara otomatis, untuk menghindari hal demikian maka pihak BKM termasuk bagian dari pengawasan produktifitas zakat fitrah.

3. Hal yang paling penting adalah sebelum melakukan produktifitas zakat fitrah, pihak pengelola harus bertanya kepada mustahak zakat apakah mustahak bersedia agar zakatnya dikelola dengan pengembangan zakat yang menjadi haknya. Jika mustahak tidak bersedia maka pihak pengelola harus memberikan zakat kepada mustahak langsung.

\section{Maqasid atau Tujuan Syara' Zakat Fitrah}

Tinjauan mengenai tujuan syara' dari kewajiban zakat fitrah dapat dilihat dari dua hadis Rasulullah saw pertama hadis riwayat Abu Dawud dan Daru Qutni.

Pertama Hadis riwayat Abu Dawud :

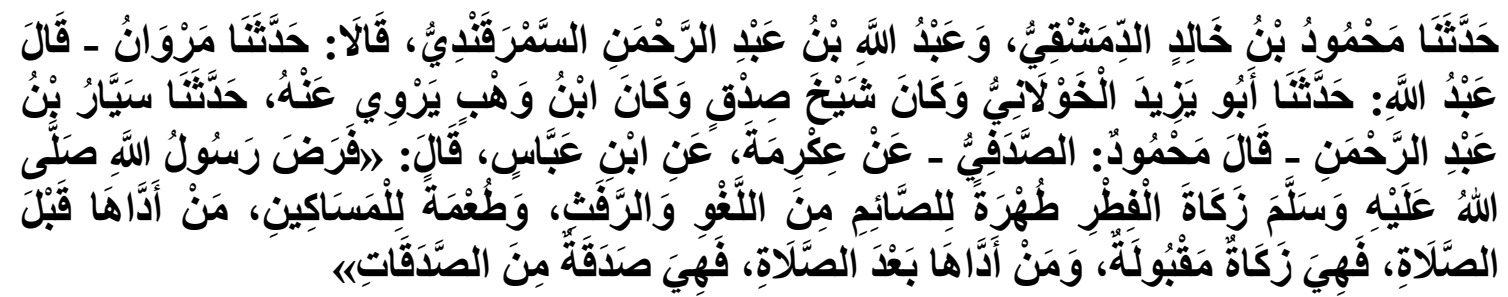

Dari Ibnu Abbas Radliyallaahu 'anhu bahwa Rasulullah Shallallaahu 'alaihi wa Sallam 
mewajibkan zakat fitrah sebagai pembersih bagi orang yang berpuasa dari perkataan yang tidak berguna dan kotor, dan sebagai makanan bagi orang-orang miskin. Maka barangsiapa yang mengeluarkannya sebelum sholat, ia menjadi zakat yang diterima dan barangsiapa mengeluarkannya setelah sholat, ia menjadi sedekah biasa.

Berdasarkan hadis di atas tujuan / Maqasid dari zakat fitrah itu adalah pembersih bagi orang yang berpuasa, yaitu membersihkan dari perkataan yang tidak bergun, keji dan kotor, yang munkin dilakukan orang yang berpuasa selama puasa Ramadan, dengan puasa Ramadan yang dilakukannya dapat mennsucikannya dari perkataan-perkataan tidak baik itu, hal ini diungkapkan oleh Abdul Muhsin al- $\operatorname{Ibad}^{23}$ :

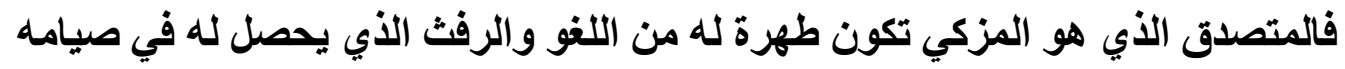

"Orang yang berzakat dengan zakatnya itu dapat mensucikan dirinya dari perkataan yang tidak berguna dan keji yang munkin dilakukannya pada saat berpuasa".

Yang kedua tujuan syara' dari zakat fitrah itu adalah memberikan makan kepada orang miskin, pada hari raya idul fitri keidentikan hari raya dengan menyajikan makanan antar keluarga sangat dirasakan sekali pada saat usai pelaksanaan salat Idul Fitri. Oleh karena itu Islam melihat jangan ada di tengah-tengah hari raya idul fitri itu ada golongan umat Islam yang tidak dapat makan atau tidak makan, dengan membayar zakat fitrah, dapat mambantu umat Islam untuk merayakan hari raya tersebut dengan menghidangkan makanan.

Tujuan syara' ketiga dari kewajiban zakat fitrah adalah : mencukupkan kebutuhan orang miskin sehingga mereka bergembira pada hari itu. Hal ini berdasarkan hadis riwayat Dar Qutni :

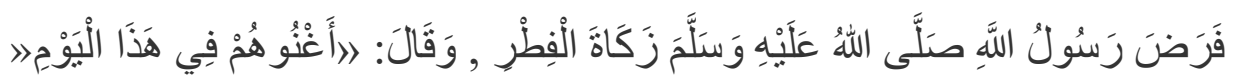

"Rasulullah saw mewajibkan zakat fitri dan bersabda, 'Cukupkan kebutuhan mereka (fakir miskin dari meminta-minta) pada hari itu'." (HR. Daruqutni).

Menurut Wahbah Zuhaili, berdasarkan hadis di atas maka tujuan Syara' zakat fitrah itu adalah ${ }^{24}$ :

\section{إغناء الفقراء عن السؤال يوم العيد}

"Mencukupkan kebutuhan para fakir dari meminta-minta pada hari raya idul fitri".

Dengan terpenuhinya kebutuhan fakir dan miskin pada hari raya idul fitri maka mereka dapat bergembira pada hari itu, karena kebutuhan mereka telah dipenuhi melalui zakat fitrah. Hari raya itu adalah hak setiap umat Islam untuk merayakannya, sangat

\footnotetext{
${ }^{23}$ Abdul Muhsin al-Ibbad, Syarah Sunan Abi Dawud (Beirut : Dar al-Fikr, t.t.), jil 8, h. 492.

${ }^{24}$ Wahbah, al-Fiqh, jil 3, h. 2037.
} 
ironi jika pada hari raya itu masih terdapat umat Islam yang tidak bisa ikut merayakannya karena alasan miskin dan fakir, Islam mengingingkan agar hari raya dapat dinikmati setiap umat Islam, melalui zakat fitrah mereka dapat menikmati dan merayakannya.

Jika Maqasid atau tujuan dari zakat fitrah dapat terpenuhi melalui pendayagunaan zakat yaitu produktifitas zakat fitrah maka pelaksanaan produktifitas zakat fitrah dapat ditinjau dari dua aspek :

1. Produktifitas zakat fitrah dapat dilakukan jika di suatu daerah terdapat segolongan orang fakir miskin dan segolongan orang kaya. Keberadaan orang kaya dalam suatu daerah sangat menentukan pelaksanaan produktifitas zakat fitrah.

2. Produktifitas zakat fitrah tidak dapat dilakukan jika mayoritas penduduk suatu daerah tergolong miskin. Ketiadaan orang kaya menyebabkan sulitnya pelaksanaan produktifitas zakat fitrah, karena menahannya sama dengan menzalimi mereka karena hak mereka tidak ditunaikan.

Dengan demikian memperhatikan dua konsep di atas dengan konsep Maqasid yang ada pada zakat fitrah, jika terdapat orang kaya dan orang miskin dalam suatu daerah, zakat fitrah dapat dibagi sebagian, kemudian sisanya diproduktifkan, atau jika seluruh mustahak setuju, zakat fitrah tidak menjadi masalah bagi mereka dengan produktifitasnya, maka zakat fitrah tidak mengapa tidak dibagikan melainkan diproduktifkan seluruhnya.

Berdasarkan pantauan penulis, saat ini sangat sulit mesjid atau badan pengumpul zakat fitrah yang melakukan produktifitas zakat fitrah, yang sangat mudah ditemukan adalah produktifitas zakat mal atau pemanfaatan benda wakaf, namun penerapan produktifitas zakat fitrah itu dapat dilakukan perhitungannya secara ekonomi mikro dengan perhitungan ekonomi yang sederhana. Sebagai contoh mesjid muslimin teladan mengumpulkan zakat fitrah sebanyak 20 juta dengan jumlah mustahak fakir dan miskin sebanyak 20 orang. Pembagian zakat fitrah dibagikan secara merata dengan ketentuan 1 orang sebanyak 1 juta.

Badan Kenaziran Mesjid memiliki kebijakan untuk memproduktifkan zakat fitrah dengan sosialisasi terlebih dahulu, ternyata melalui program yang ditawarkan nazir sebanyak 10 orang menyetujui produktifitas zakat fitrah dengan menyerahkan 500 ribu kepada mustahak dan 500 ribu lagi akan diproduktifkan. Modal produktifitas zakat fitrah sebanyak 5 juta. Adapun usaha produktif yang dikembangkan nazir atau pihak 
manapun yaitu dengan usaha cuci mobil dan kereta, setiap bulan keuntungan dari usaha itu sebanyak 5 juta. Keuntungan dari usaha cuci mobil dibagi kepada para mustahak dengan pembagian 500 ribu per-individu dalam setiap bulan.

Hal ini sangan membangun ekonomi umat walaupun masih dalam ruang lingkup kecil, jika zakat fitrah itu diberikan secara keseluruhan, maka efek negatifnya adalah dana zakat fitrah itu akan habis segera mengingat kebutuhan yang tidak terbatas, namun dengan memproduktifkannya,maka setiap bulan para mustahak akan menikmati hasil dari uasaha produktifitas zakat fitrah.

\section{Pemberdayaan Ekonomi Umat Melalui Produktifitas Zakat Fitrah}

Menurut beberapa pakar ekonom Pemberdayaan di bidang ekonomi merupakan upaya untuk membangun daya (masyarakat) dengan mendorong, memotivasi, dan membangkitkan kesadaran akan potensi ekonomi yang dimilikinya serta berupaya untuk mengembangkannya. Keberdayaan masyarakat adalah unsur dasar yang memungkinkan suatu masyarakat bertahan. Dalam pengertian yang dinamis, yaitu mengembangkan diri dan mencapai kemajuan. Keberdayaan masyarakat menjadi sumber dari apa yang dikenal sebagai Ketahanan Nasional ${ }^{25}$.

Selain itu menurut Soeharto pemberdayaan menunjuk pada kemampuan orang, khususnya kelompok rentan dan lemah sehingga mereka memiliki kekuatan atau kemampuan dalam (a) memenuhi kebutuhan dasarnya sehingga mereka memiliki kebebasan (freedom) dalam arti bukan saja bebas mengemukakan pendapat, melainkan bebas dari kelaparan, bebas dari kebodohan, dan bebas dari kesakitan (b) menjangkau sumber-sumber produktif yang memungkinkan mereka dapat meningkatkan pendapatannya dan memperoleh barang-barang dan jasa-jasa yang mereka perlukan (c) berpartisipasi dalam proses pembangunan dan keputusan-keputusan yang mempengaruhi kehidupan mereka ${ }^{26}$.

Memberdayakan ekonomi umat di sini, berarti upaya untuk meningkatkan harkat dan martabat lapisan masyarakat Islam dari kondisi tidak mampu, serta melepaskan diri dari perangkap kemiskinan dan keterbelakangan ekonomi. Dengan kata lain, sebagai upaya membangun kemandirian umat di bidang ekonomi. Atau dengan kata lain pemberdayaan ekonomi umat adalah upaya untuk membangun daya (masyarakat) dengan mendorong, memotivasi, dan membangkitkan kesadaran akan potensi yang

\footnotetext{
${ }^{25}$ Mubyarto, “Membangun Sistem Ekonomi”, (Yogyakarta: BPFE, 2000), h.263-264.

26 Edi Suharto, "Membangun Masyarakat Memberdayakan Rakyat", (Bandung: PT Refika Aditama,2005), h.58-59.
} 
dimilikinya serta berupaya untuk mengembangkannya seperti; melakukan upaya peningkatan kemampuan untuk menghasilkan nilai tambah paling tidak harus ada perbaikan akses terhadap empat hal, yaitu akses terhadap sumber daya, akses terhadap teknologi, akses terhadap pasar, akses terhadap permintaan.

Dengan demikian sebenarnya hakikat dari Pemberdayaan ekonomi umat melalui produktifitas zakat fitrah yaitu adanya upaya untuk mengelola dana zakat fitrah tersebut kepada usaha yang produktif yang dapat menghasilkan suatu perolehan keuntungan dimana hasil produktifitas dari zakat fitrah tersebut dapat dinikmati para mustahak untuk selamanya tidak habis begitu saja.

Tujuan dari Produktifitas zakat fitrah ini adalah untuk membangun kemandirian umat di bidang ekonomi serta membebaskan mereka dari genggaman kemiskinan, dan yang paling penting adalah pemberdayaan ekonomi umat melalui produktifitas zakat fitrah dalam jangka panjang adalah dapat merubah keadaan mustahak zakat menjadi muzakki.

\section{E. Contoh Pemberdayaan Ekonomi Umat Melalui Zakat Fitrah}

Berdasarkan pengalaman penulis yang pernah terlibat langsung dalam pembagian zakat fitrah, biasanya zakat yang terkumpul dalam satu mesjid tidak dapat dipastikan jumlahnya, tergantung masing-masing mesjid, ada yang mendapatkan zakat berupa uang sebesar Rp. 30.000 .0000 jika mesjid tersebut termasuk dalam kategori mesjid yang sedang tidak terlalu besar, ada yang mendapatkan bahkan lebih dari Rp. 100.000.000 karena mesjid itu dikategorikan mesjid jami' yaitu mesjid besar kemudian memiliki jamaah mesjid yang dermawan dan memiliki materi yang cukup banyak. Selain itu bahkan ada yang hanya memperoleh zakat fitrah di bawah Rp. 10.000.000.karena mesjid itu dikategorikan sebagai mesjid kecil dan jamaahnya adalah jamaah yang memang dikategorikan ekonomi menengah ke bawah.

Sebenarnya berapapun hasil dari zakat yang diperoleh tidak memiliki pengaruh yang besar, karena dalam pemberdayaan ekonomi umat melalui produktifitas zakat fitrah adalah bagaimana mengelola dan mengembangkan dana zakat itu. Menurut M. Daud Ali pemanfaatan dana zakat dapat dikategorikan sebagai berikut

1. Pendayagunaan yang konsumtif dan tradisonal sifatnya dalam kategori ini penyaluran diberikan kepada orang yang berhak menerimanya untuk dimanfaatkan langsung oleh yang bersangkutan seperti: zakat fitrah yang diberikan kepada fakir miskin untuk memenuhi kebutuhan sehari-hari atau zakat harta yang diberikan kepada korban bencana alam. 
2. Pendayagunaan yang konsumtif kreatif, maksudnya penyaluran dalam bentuk alat-alat sekolah atau beasiswa dan lain-lain.

3. Pendayagunaan produktif tradisional, maksudnya penyaluran dalam bentuk barang-barang produktif, misalnya kambing, sapi, mesin jahit, alat-alat pertukangan, dan sebagainya. Tujuan dari kategori ini, untuk menciptakan suatu usaha atau memberikan lapangan kerja bagi fakir miskin.

4. Pendayagunaan produktif kreatif, pendayagunaan ini di wujudkan dalam bentuk modal yang dapat dipergunakan baik untuk membangun sebuah proyek sosial maupun untuk membantu atau menambah modal seorang pedagang.

Bentuk dan sifat pemberdayaan dapat disalurkan dengan berbagai macam cara, ini dilakukan untuk mencapai satu tujuan yang sama yaitu: untuk memandirikan masyarakat, mengurangi tingkat kemiskinan dan menjadi solusi tepat dalam mensejahterakan umat. Di antara contoh dari pemberdayaan ekonomi umat melalui produktifitas zakat fitrah melalui program-program jitu yaitu :

A. Qardhul Hasan (pinjaman kebajikan, yakni kredit tanpa bunga)

B. Mudharabah (bagi hasil) melalui Program Pemberdayaan Modal Usaha bagi Pedagang Kecil (PPMUPK) yang dalam pelaksanaannya melibatkan BMT (Baitul Maal wa Tamwil). Sebagai contoh pedagang diberi modal oleh BKM dengan kesepakan bagi hasil 30\% untuk BKM dan 70\% untuk pedagang. Contoh: penjual nasi uduk memerlukan modal untuk usahanya sebesar Rp 1.500.000 semisal pedangang mendapatkan untung dari hasil berjualan sekitar Rp 70.000 maka cara pembagiannya adalah Rp 20.000 untuk BKM dan Rp 50.000 untuk pedagang, dan setiap hari dikontrol keuntungannya oleh pihak BKM. Sedangkan dana Rp 1.500.000 terus diputar.

C. Pertanian Produktif, program pemberdayaan untuk mendorong petani muda melalui bantuan sarana produksi, alat mesin pertanian, bibit unggul dan pendampingan.

D. Ternak produktif, program untuk membantu petani memiliki penghasilan tambahan dari beternak, melalui bantuan bibit unggul dan sarana produksi.

\section{F. Penutup}

Dari pemaparan serta uraian yang telah penulis jelaskan di atas dapat disimpulkan bahwa :

1. Zakat produktif adalah zakat dimana harta atau dana zakat yang diberikan kepada para mustahik tidak dihabiskan akan tetapi dikembangkan dan digunakan untuk 
membantu usaha mereka, sehingga dengan usaha tersebut mereka dapat memenuhi kebutuhan hidup secara terus-menerus

2. Secara tekstual memang para ulama terdahulu di atas tidak menyebutkan secara detail harta zakat yang diperoleh apakah dibagikan secara konsumtif atau produktif namun dalam praktek pendistiribusian zakat ada indikasi yang mengarah kepada kebolehan untuk mendayagunakan zakat secara produktif, di mana ulama terdahulu ada yang membolehkan pemberian zakat kepada orangorang miskin berupa alat pekerjaan yang sesuai dengan profesi orang tersebut, yang dapat dijadikan modal bagi mereka untuk pekerjaannya dan menekuni usahanya, agar hasilnya dapat mencukupi kebutuhan mereka dalam jangka waktu yang lama bukan hanya sesaat.

3. Memberdayakan ekonomi umat di sini, berarti upaya untuk meningkatkan harkat dan martabat lapisan masyarakat Islam dari kondisi tidak mampu, serta melepaskan diri dari perangkap kemiskinan dan keterbelakangan ekonomi

4. Contoh pemberdayaan ekonomi umat melalui produktifitas zakat fitrah yaitu Qardul Hasan, Mudharabah, pertanian produktif dan pertenakan produktif.

\section{Daftar Pustaka}

Ahmad, Amrullah. Prospek Hukun Islam dalam Kerangka Pembangunan Hukum Nasional. Jakarta: Ikaha, 1994.

al-Asqalāny, Ibnu Hajar. Fath al-Bāriy Syarkhu al-Bukhāriy, Beirut : Dar al-Fikr, 1996), Juz ke-4, Bāb 'akhdzu al-shadaqati min al-'aghniyà', nomor 1496 .

Al-Buny, Djamaluddin Ahmad. Problematika Harta dan Zakat, Bina Ilmu. Surabaya: Rajawali, 1983.

Al-Ghazali. Rahasia Puasa dan Zakat. Bandung: Karisma, 1994.

Ali, Muhammad Daud. Sistem Ekonomi Islam dan Wakaf, Jakarta: UI Press, 1988.

Al-Maududi, Abdul A'la. Prinsip-Prinsip Islam. Penerjemah : Abdullah Suhaili, Bandung: Al-Ma'arif, 1988.

Al-Qardhawi, Yusuf. Fiqh al-Zakat, Beirut: Muassasat al-Raisalat, 1997, Jilid II, Cet. Ke-24.

Al-Suyûthi , Abi al-Fadl Jalāludd̄̄n 'Abdu al-Rahmān. Al-Asybāh wa al-Nazhāir. Beirut : Dar al-Fikr, 1996.

Al-Zuhayli, Wahbah. Zakat Kajian Berbagai Mazhab. Bandung : Remaja Rostakarya, 1995. 
Basyir, Ahmad Azhar. Garis Besar Sistem Ekonomi. BPEE Ekonomi UGM, Yogyakarta, 1987.

Departemena Agama RI. Al-Qur'an dan terjemahannya. Semarang: Toha Putra, 2002. Al-Qur 'an dan Pemberdayaan Kaum Dhuafa. Jakarta : Departemen Agama RI, 2008.

Dewan Redaksi Ensiklopedi Islam, Ensiklopedi Islam. Jakarta : Ichtiar Baru Van Hoeve, 1993.

Djamaluddin Ahmad Al-Bunny. Problematika Harta dan Zakat. Surabaya: Bina Ilmu, 2000.

Fachruddin. Ensiklopedi Al-Qur'an, Buku 2, Jakarta : Rineka Cipta, 1985.

Hadi, Sutrisno. Methodologi Research. Yogyakarta : Gajah Mada Universitiy Press, 1977.

Hafidhuddin, Didin. “Optimalisasi Pendayagunaan Zakat”, dalam Hamid Abidin (Ed.), Reinterpretasi Pendayagunaan ZIS: Menuju Efektifitas Pemanfataan Zakat, Infak, Sedekah, Jakarta: PIRAMEDIA, 2004. , Panduan Praktis Tentang Zakat, Infak, Sedekah. Jakarta : Gema Insani, 1998. , Zakat Dalam Perekonomian Modern. Jakarta : Gema Insani Pers, 2002.

Hamid, Arifin. Hukum Zakat Pengembangan dan Pendayagunaannya. Makassar: Umitoha Ukhuwah Grafika, 2006.

Hasan, M. Ali. "Masail Fiqhiyah", Zakat, Pajak, Asuransi,dan Lembaga Keuangan. Jakarta: Raja Grafindo Persada, 1996.

Hasan, Sofyan. Pengantar Hukum Zakat dan Wakaf. Surabaya: Al-Ikhlas, 1994.

Jamal, Ibrahim Muhammad. Fiqih Muslimah Ibadat-Muamalat. Jakarta: Pustaka Amani, 1999.

Karim, M. Rusli. Berbagai Aspek Ekonomi Islam. Yogyakarta : PT. Tiara Wacana, 1992.

Kelib, Abdullah. Metodelogi Penelitian Fiqh dan Hukum Sekuler, Masalah-masalah Hukum. Majalah FH. UNDIP, No.5-1995.

Mahfudh, Sahal. Nuansa Figh Sosial. Yogyakarta: Pustaka Pelajar, 1994.

Mardjono, Hartono. Prospek Keuangan Umat Kontemporer. Yogyakarta: UII Press, 2000.

Mas'udi, Masdar F. Agama Keadilan: Risalah Zakat (Pajak) dalam Islam. Jakarta : Pustaka Firdaus,1991.

Moleong, Lexi J. Metodologi Penelitian Kualitatif, Bandung : Remaja Rosda Karya, 1990. 
Mulkan, Abdul Munir. Masalah-masalah Teologi dan Fiqh dalam Tarjih Muhammadiyah. Yogyakarta: SI-Press, 1994.

Nadwi, Abul Hasan Ali. Ibadah: Shalat, Zakat, Puasa, Haji. Penerjemah: Hery Noer Ali, Bandung: Risalah, 1985.

Nawawi, Hadari dan Himi Martini. Penelitian Terapan. Yogyakarta: Gajah Mada University Press, 1996. 